DOI: doi.org/10.18372/38232

UDC: 665.753

\title{
2.8 MODIFICATION OF DIESEL FUEL COMPOSITION WITH METHYL ESTERS OF FATTY ACIDS FROM NON-EDIBLE FATS
}

\author{
Elena Shevchenko, Valeriia Kameneva, Alyona Shkekina
}

The demand for oil will be growing by $1 \%$ per year until 2035 , all over the world. As a result, instead of the current 84.5 million barrels per day, the global market will need 111.7 million barrels a day. Oil consumption will reach 106 million barrels a day in 2030. This is in line with the forecast of the International Energy Agency.

Forecasts show that the existing energy efficiency policy and the role of alternative fuels with high energy prices will curb the growth of energy consumption and ensure the transition to renewable energy sources.

Solution of the modern environmental problems requires the search for alternative sources of raw materials and energy. It is related not only to the need to reduce pollution of the environment, but also the importance of the transition from exhaustible raw materials to the increased use of renewable resources. Work in this direction has been conducted around the world for a long time. Oil crops are the most important source of renewable raw materials among modern bioresources, because vegetable oils could be used to produce fuels and lubricants as an alternative to petroleum raw materials. The renewability of the raw materials causes the expediency of expanding the use of vegetable oils in technology at present. In addition, the products derived from vegetable oils have less reliable as compared with the synthetic products, which are biodegradable [2].

An important fact is that the use of fats and fatty waste is possibly not only in the production of lubricants, but also in the production of fuels - gasoline, diesel, boiler houses. This makes it possible to use machines and mechanisms that work only on products of plant origin.

At present, Ukraine has a shortage of oil fuels (oil and gas condensate production is below 4 million tons, lacking more than 10 million tons), while production of biofuels from vegetable oils (rapeseed, sunflower, etc.) is relatively cheap process. Therefore, this is a promising area for research. Fuels of vegetable origin from rapeseed oil (a mixture of rapeseed oil fatty acid methyl esters) and glycerol are produced by methanolysis. Currently, more than 1.5 million tons of biofuels are produced in Europe (Germany, France, Austria, etc.).

Biodiesel can be used in diesel engines without constructional changes or swap. Fuel consumption is increased by $10 \%$ when the engine is running on biodiesel (methyl esters of fatty acids are oxygen-fueled). The emission of harmful substances in the exhaust gases is reduced by $25-50 \%$. Therefore, this type of fuel can be used in environmentally sensitive areas (city zone, recreation area, etc.) [1].

Biofuels of the first generation are made according to the traditional technologies of sugar, starch, vegetable oil and animal fat. The main sources of raw materials are seeds or fruits. For example, vegetable oils are obtained by pressing seeds of sunflower. The resulting oil can be used to produce biodiesel. The starch is obtained from wheat. After transformation of starch, bioethanol is produced. But such sources of raw material are important in the food chain of people and animals. In addition, many first-generation biofuels are investment intensive and cannot compete with fossil fuels by value (for example, oil). Some first-generation fuels slightly reduce greenhouse gas emissions. Emissions from the production and transportation of the first-generation fuels often exceed emissions from the use of conventional fossil fuels [3].

The main task of biofuel technology of the second generation is to increase the amount of biofuel made of residual non-food parts of plants remaining after the removal of the food part, such 
as stems, leaves, husk. Non-food plants (millet, jatropha) and industrial waste, such as wood chips, peel and pulp from fruit pressing, etc., can also be used for the production of the second generation fuels.

The second generation biofuels technologies are designed to extract useful substances for the production of fuels using wood biomass. Wood biomass contains useful sugars in cellulose and lignin. All plants contain cellulose and lignin. They are complex carbohydrates (molecules based on sugar).Lignocellulosic ethanol is obtained by separating sugar molecules from cellulose, using enzymes, steam heating and other pretreatments.Ethanol can be obtained from sugar base using fermentation as well as in the processes of the first processing. The by-product of this process is lignin, which can be used to generate energy. Obtaining ethanol from lignin and cellulose reduces greenhouse gas emissions by $90 \%$ compared with petroleum [3].

The first and second generation biofuels use existing technologies for the production of alcohol and vegetable oils. While the third generation of biofuels uses new technologies with photosynthetic algae. These algae use energy of light to absorb carbon dioxide from the air and produce organic compounds. Microalgae have very small size about 1, 2, 3, 10 micrometers. They are able to produce a lot of lipids inside their cells. Lipids can be isolated and transformed into biofuels. Microalgae grow up very quickly, do not occupy land areas, and are technologically processed.

Algae can be used to produce motor fuels that are very similar to the traditional ones. The microalgae have the following benefits:

- $\quad$ high yield;

- $\quad$ ability to develop in water, not on the ground, which can be used for other food crops;

- ability to absorb large amount of carbon dioxide; and

- $\quad$ low use water for cultivation.

The paths for biomass conversion into biofuels of the first, second and third generations are shown in Fig. 1.

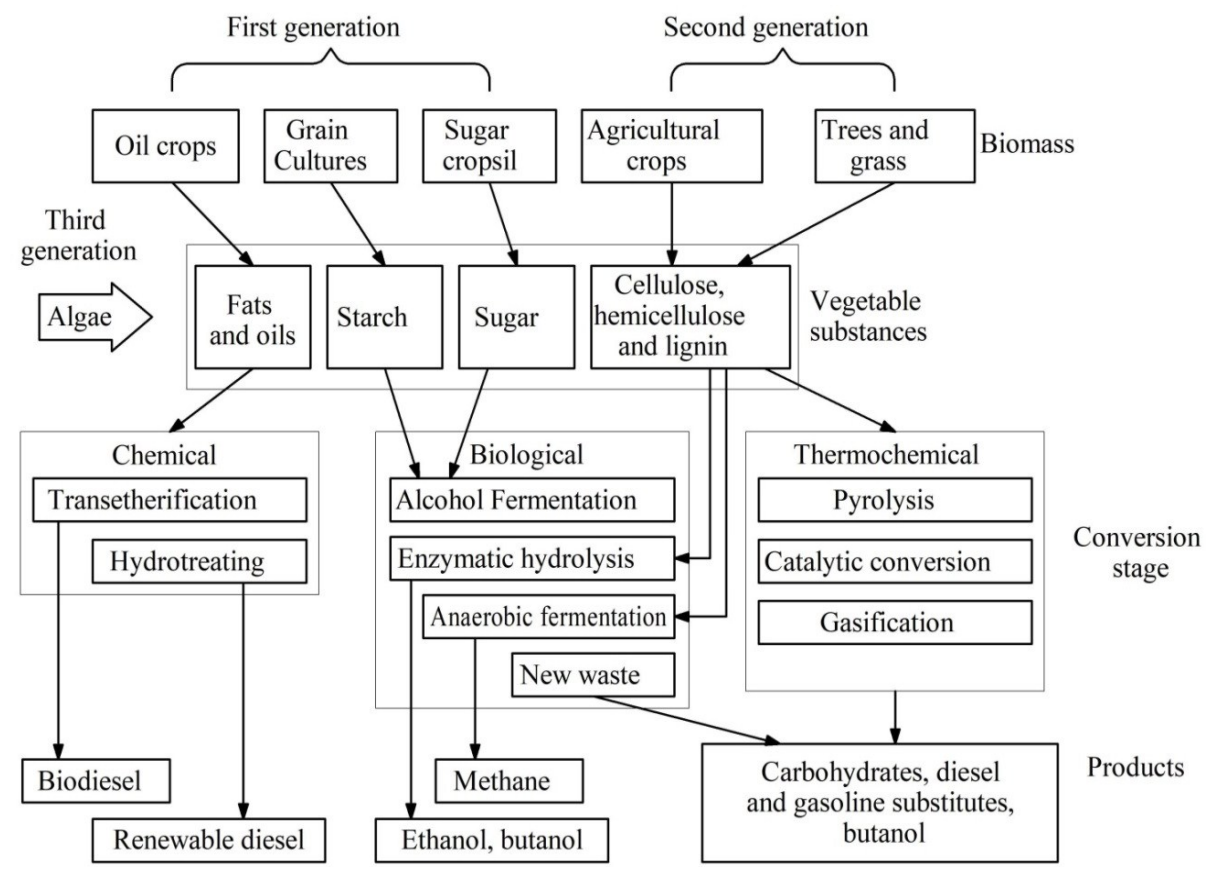

Fig. 1. Ways of biomass conversion for biofuels of the first, second and third generations [4]. 
At first, microalgae should be grown. Then this biomass should be collected.The collected algae can be immediately sent for recycling. The hydrocracking process will take place and the fraction of bio-oil will be separated at high pressure and temperature. This bio-oil can be purified by conventional petroleum distilleries. There is another option. First, the separated microalgal biomass fraction can be isolated and then recycled into biofuels by chemical methods. So, there is a range of technologies.

Microalgae provide an opportunity to get by order of magnitude more biofuels as compared with conventional crops. The agricultural crops grow for a long time, and microalgae grow in 2 weeks.

There is no algae fuel in Ukraine due to the absence of strains. Algae strains that can be used in the industry are costly. But such algae can be a promising source of raw materials for the production of biodiesel fuel. Data indicate that 1 hectare of land can give 446 liters of soybean oil or 2690 liters of palm oil, while the same area of the water surface can yield about 90.000 liters of biodiesel. The development of the third-generation biofuels production is an important task for Ukraine.

The development of alternative energy sources and the production of biofuels are topical in our time due to the energy crisis. Biofuel production from microalgae has a number of significant advantages over the production of biofuels from oilseeds and rape. But now the project for obtaining biofuels from algae is only at the stage of experimental development.

The fourth generation of biofuels is a technology using photosynthetic cyanobacteria. Bacteria produce the final product using $\mathrm{CO}_{2}$ and sunlight. This method greatly increases the system performance. The photosynthetic cell can be genetically modified for ethanol production. The surface of water in a special reactor, where the cyanobacteria live, is heated by sunlight. The alcohol evaporates from the surface of the water and is collected by condensation. This is a very interesting process without intermediate stages of biomass collection and processing. By now, such technology is under development in the USA.

The fifth generation of biofuels is now being developed. Electric biosynthesis is the basis of this process. There are microbes that can consume electricity from the electrode in solution. These microbes perform very high energy conversion efficiency, potentially. Some microorganisms are able to use up to $80 \%$ of the electrons obtained from the electrode for the synthesis of organic compounds. The processes of obtaining biofuels of the fifth generation do not affect agricultural areas and drinking water. The use of electric biosynthesis may increase the production of food and biofuels [4].

The National standard of Ukraine 4840:2007 «Diesel fuel of high quality. Specifications» limits the content of methyl esters of fatty acids by not more than $5 \%$. Sunflower and rapeseed oils are traditional sources of triglycerides in Ukraine. The production of biofuels from this raw material is limited by its high price (sunflower oil of the 1 st grade is $22 \mathrm{UAH} / \mathrm{kg}$, rapeseed oil is up to $18 \mathrm{UAH} / \mathrm{kg}$ ), and is now not economically profitable. In addition, large agricultural areas should be used to grow these crops. It is more rational to use sunflower oil as a food product, and it is better to import rapeseed oil. Non-standard vegetable oils (such as worked or dark sunflower oil) can be used to synthesize biofuels.

A significant amount of technical animal fat is available in Ukraine. Non-food animal fats are of lower value than high quality vegetable oils. For example, if the fats do not meet the standards of color, transparency, contain impurities, etc. they can be used for FAME synthesis. This is a mixture of pork-beef fat, chicken fat and fish oil, they are meat-processing residues. Approximate price of such fats: pork beef -10 grn, chicken -12 and fish -6 grn per kilogram.

Technical pork-beef fat is burned. Chicken and fish oils are partly used as additives to animal feed. The rest, which is most of the chicken and fish oil, can go for FAME. Ukrainian enterprises receive about 1000 tons of chicken fat per month. 
The advantages of using technical fats and oils are: availability throughout the year, independence from the weather conditions, safe process of transesterification. The production of fuel or fuel components from waste companies can reduce the self-cost of products. Also, the use of biofuels can increase the level of energy independence of the country.

We used chicken fat, fish oil, pork beef fat and palm oil, sunflower oil and soybean oil as raw material for the synthesis of fatty acid methyl esters. Such a wide range is due to the following factors: sunflower oil and soybean oil are best studied and widespread; palm oil and technical fish oil are the cheapest; pork-beef fat and chicken fat are undocumented industrial waste. The processing of technical animals of low-fat fats is not only an additional source of raw materials for the synthesis of the MES, but also a partial solution to the problem of waste recycling in the food industry.

All samples of the FAME were synthesized by specialists at the Department of Chemical Technology of High-Molecular Compounds, and the study of the physical-chemical properties of the FAME was carried out at the Department of Chemical Technology of Fuels at the Test Laboratory of Petroleum Products at the Ukrainian State Chemical-Technological University.

The transesterification reaction allows obtaining products close to diesel fuel according to physical and chemical and operational characteristics. But methyl esters of fatty acids are unsuitable as an additive to fuels for a number of indicators, although this possibility is considered in some cases. We have investigated samples of products derived from Ukrainian raw materials in comparison with diesel fuel (Table 1).

Table 1

Properties of fatty acid methyl esters from fats and oils

\begin{tabular}{|c|c|c|c|c|c|c|c|c|}
\hline \multirow[b]{2}{*}{ Property } & \multirow[b]{2}{*}{$\begin{array}{l}\text { Standar } \\
\text { d } \\
\text { EN } 590\end{array}$} & \multirow[b]{2}{*}{$\begin{array}{l}\text { Diesel } \\
\text { Class } \\
\text { C }\end{array}$} & \multicolumn{6}{|c|}{ Fatty acid methyl esters (FAME) } \\
\hline & & & 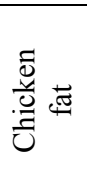 & 氞芯 & $\begin{array}{l}\overline{0} \\
\dot{0} \\
\overline{0} \\
0 \\
\stackrel{0}{\leftrightarrows} \\
\Xi \\
\bar{n}\end{array}$ & $\begin{array}{l}\bar{\sigma} \\
\text { ते } \\
\text { के }\end{array}$ & $\begin{array}{l}\bar{\sigma} \\
\Xi \\
\bar{\Xi} \\
2\end{array}$ & 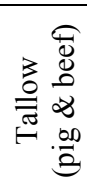 \\
\hline $\begin{array}{l}\text { 1.Distillation recovered } \\
\text { at } 250{ }^{\circ} \mathrm{C}, \% \mathrm{~V} / \mathrm{V} \\
350{ }^{\circ} \mathrm{C}, \% \mathrm{~V} / \mathrm{V} \\
95 \% \mathrm{~V} / \mathrm{V} \text { recovered } \\
\text { at, }{ }^{\circ} \mathrm{C}\end{array}$ & $\begin{array}{l}65 \\
85 \\
\\
360\end{array}$ & $\begin{array}{r}49 \\
87 \\
\\
360\end{array}$ & $\begin{array}{c}- \\
100 \\
-\end{array}$ & $\begin{array}{c}- \\
100 \\
-\end{array}$ & $\begin{array}{c}6 \\
75 \\
360\end{array}$ & $\begin{array}{c}- \\
100 \\
-\end{array}$ & $\begin{array}{c}- \\
100 \\
-\end{array}$ & $\begin{array}{c}- \\
100 \\
-\end{array}$ \\
\hline 2.Boiling range, ${ }^{\circ} \mathrm{C}$ & - & $\begin{array}{c}180- \\
360\end{array}$ & $\begin{array}{c}298- \\
340\end{array}$ & $\begin{array}{c}324- \\
348\end{array}$ & $\begin{array}{c}302- \\
360\end{array}$ & $\begin{array}{c}259- \\
348\end{array}$ & $\begin{array}{c}290- \\
350\end{array}$ & $\begin{array}{c}318- \\
350\end{array}$ \\
\hline 3.Cetane no. min. & 51 & 51 & 54 & 56 & 53 & 54 & 52 & 53 \\
\hline 4.Density at $15^{\circ} \mathrm{C}, \mathrm{kg} / \mathrm{m}^{3}$ & $\begin{array}{c}820- \\
845\end{array}$ & 825 & 899 & 896 & 899 & 892 & 889 & - \\
\hline $\begin{array}{l}\text { 5. Kinematic viscosity at } \\
40^{\circ} \mathrm{C}, \mathrm{mm}^{2} / \mathrm{s}\end{array}$ & $2,0-4,5$ & 3,5 & 8.32 & 6.58 & 5.4 & 6.68 & 7.19 & 7.12 \\
\hline $\begin{array}{l}\text { 6.Flash point, closed cup } \\
{ }^{\circ} \mathrm{C} \text {, min. }\end{array}$ & $\geq 55$ & 55 & 159 & 142 & 154 & 151 & 169 & 165 \\
\hline 7.Pour point, ${ }^{\circ} \mathrm{C}$ & - & -14 & -3 & -5 & -7 & -3 & 5 & 6 \\
\hline 8.Cloud point, ${ }^{\circ} \mathrm{C}$ & - & -4 & 7 & 0 & 0 & 2 & 15 & 21 \\
\hline 9.CFPP,${ }^{\circ} \mathrm{C}$ & $-5 /-20$ & -8 & 2 & -4 & -1 & -1 & 9 & 20 \\
\hline 10.Acid no., mg KOH/g, & - & - & 2,1 & 2,0 & 0,029 & 2,2 & 0,75 & 0,75 \\
\hline 11.Sulphur content, $\mathrm{mg} / \mathrm{kg}$ & $\leq 10$ & 10 & 9 & 2 & 0 & 0 & 0 & 0 \\
\hline 12.Ash content, $\% \mathrm{~m} / \mathrm{m}$ & $\leq 0,01$ & 0,01 & 0 & 0,006 & 0,029 & 0,016 & 0,05 & 0,015 \\
\hline 13.Iodine Value, $\mathrm{g} \mathrm{l}_{2} / 100 \mathrm{~g}$ & - & - & 89,1 & 91,6 & 101,7 & 96,9 & 60,0 & 60 \\
\hline
\end{tabular}


Significant deviations exist in such properties as: fractional composition, viscosity, density, acid number, iodine value, low-temperature properties. But some of these indicators fit into the norms, as biodiesel is used only as an additive to fuel. First of all, it refers to the viscosity (Fig. 2) and density (Table 1, Fig. 3).

Analysis of viscosity-temperature dependence of the biodiesel fuel samples

Table 2

\begin{tabular}{|l|c|c|c|c|c|c|c|c|c|c|}
\hline \multirow{2}{*}{$\begin{array}{c}\text { Fatty acid methyl } \\
\text { esters (FAME) }\end{array}$} & \multicolumn{10}{|c|}{ Kinematic viscosity, $\mathrm{mm}^{2} / \mathrm{s}$ at, ${ }^{\circ} \mathrm{C}$} \\
\cline { 2 - 13 } & 10 & 20 & 30 & 40 & 50 & 60 & 70 & 80 & 90 & 100 \\
\hline Fish fat & 15,6 & 11,4 & 8,67 & 6,33 & 5,1 & 4,43 & 3,76 & 3,22 & 2,82 & 2,46 \\
\hline Soy oil & 12,36 & 8,63 & 6,71 & 5,42 & 4,4 & 3,81 & 3,04 & 2,62 & 2,27 & 2,0 \\
\hline Palm oil & - & - & - & 7,28 & 5,8 & 4,73 & 3,95 & 3,31 & 2,85 & 2,51 \\
\hline Chicken fat & - & - & - & 8,95 & 7,03 & 5,6 & 4,65 & 3,85 & 3,29 & 2,95 \\
\hline Sunflower oil & 15,62 & 11,25 & 8,69 & 6,32 & 5,05 & 4,24 & 3,81 & 3,21 & 2,77 & 2,42 \\
\hline
\end{tabular}

Graphs of viscosity-temperature dependence are built according to the data of Table 2.

The excess of these indicators will not greatly affect the processes of mixture formation and combustion, due to the fact that biodiesel is a strong surfactant.

The low-temperature properties of mixed fuels are unsatisfactory. This limits their use only in warm seasons. Numerous attempts to lower pour points and filterability with depressor additives made it possible to establish that there are polyalkyl methacrylate additives in a concentration of up to $1 \%$ or copolymers of ethylene with vinyl acetate. However, the effect of these additives is individual and applies only to the studied samples. On the other hand, this indicates the possibility and selection of effective depressors.

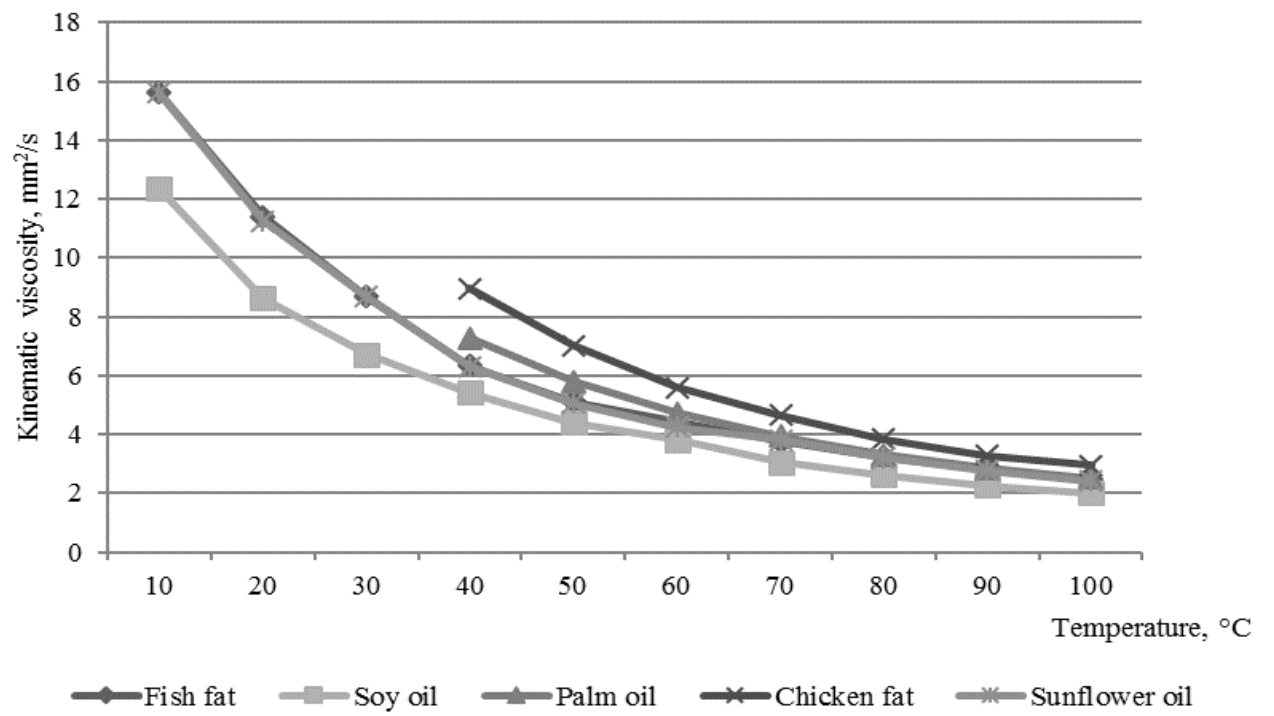

Fig. 2. Viscosity-temperature dependence of biodiesel fuel on the basis fats and oils 

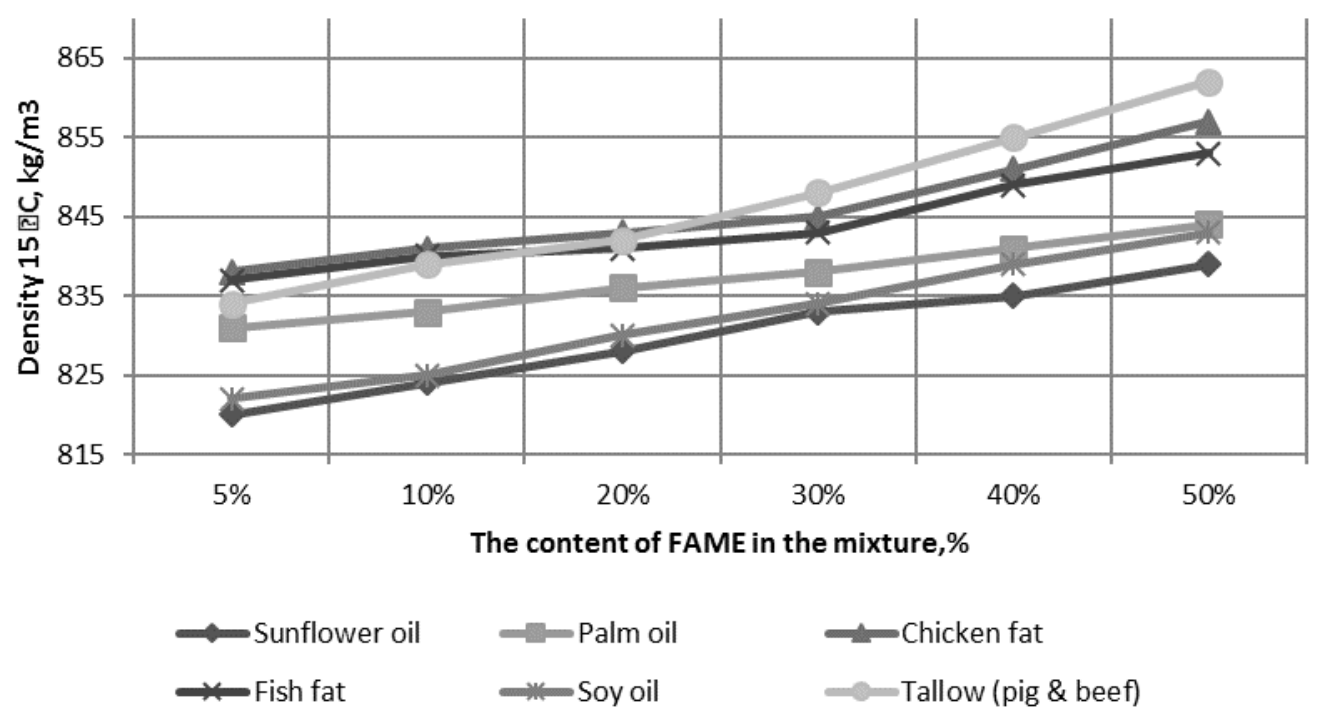

Fig. 3. Density dependence of biodiesel fuel on the basis fats and oils

A high iodine number depends on the fatty acid composition of biodiesel, more precisely, on the amount of unsaturated esters. This can adversely affect the thermal-oxidative stability of the mixed fuel.

The fatty acid composition of biodiesel was determined with chromato-aspirometer on the HP 6890 chromatograph with a flame ionization detector and a HP-INNOWax capillary column. $l=30 \mathrm{~m}, d=0.53 \mathrm{~mm}, h=1 \mu \mathrm{m}$, Conditions: -injector temperature is $220^{\circ} \mathrm{C}$, detector temperature is $275{ }^{\circ} \mathrm{C}$, hydrogen flow rate $-30 \mathrm{ml} / \mathrm{min}$, air flow rate $-300 \mathrm{ml} / \mathrm{min}$, Helium flow rate $10 \mathrm{ml} / \mathrm{min}$; Sample volume $-1 \mu \mathrm{l}$. The results of the analysis are presented in Table.

Table 3

Typical fatty acid (FA) groups in fatty acid methyl esters from fats and oils

\begin{tabular}{|l|c|c|c|c|c|c|}
\hline \multirow{2}{*}{ Property } & \multicolumn{5}{|c|}{ Fatty acid methyl esters (FAME) } \\
\cline { 2 - 7 } & $\begin{array}{c}\text { Chicken } \\
\text { fat }\end{array}$ & $\begin{array}{c}\text { Fish } \\
\text { fat }\end{array}$ & $\begin{array}{c}\text { Sunflower } \\
\text { oil }\end{array}$ & $\begin{array}{c}\text { Soy } \\
\text { oil }\end{array}$ & $\begin{array}{c}\text { Palm } \\
\text { oil }\end{array}$ & $\begin{array}{c}\text { Tallow } \\
\text { (pig \& beef) }\end{array}$ \\
\hline Myristic acid, $\mathrm{C}_{14-0}$ & - & 9,1 & - & 0,06 & 3,03 & 5,05 \\
\hline Palmitic acid, $\mathrm{C}_{16}: 0$ & 17,8 & 21,2 & 5,8 & 9,96 & 34,74 & 29,4 \\
\hline Palmitoleic acid, $\mathrm{C}_{16}: 1$ & 4,7 & 9,2 & 0,2 & 0,06 & 0,41 & 2,0 \\
\hline Stearic acid $\mathrm{C}_{18}: 0$ & 5,2 & 7,5 & 3,4 & 6,61 & 4,5 & 16,7 \\
\hline Oleic acid $\mathrm{C}_{18}: 1$ & 37,9 & 24,9 & 69,2 & 25,6 & 40,5 & 38,0 \\
\hline Linoleic acid $\mathrm{C}_{18}: 2$ & 33,4 & 3,4 & 19,6 & 51,16 & 16,4 & 6,8 \\
\hline Linolenic acid $\mathrm{C}_{18}: 3$ & 0,4 & 1,3 & 0,5 & 6,4 & 0,02 & 0,5 \\
\hline Eicosanoic acid $\mathrm{C}_{20}: 0$ & 0,4 & 9,2 & 0,5 & - & - & 0,15 \\
\hline Behenic acid $\mathrm{C}_{22}: 0$ & - & 13,0 & 0,4 & - & - & 0,55 \\
\hline Others & 0,2 & 1,2 & 0,4 & 0,15 & 0,4 & 0,85 \\
\hline
\end{tabular}

Oxidative stability was determined by three methods. 
Method EN 14112 is Rancimat test. According to this method, a stream of air is passed through the sample at a given temperature. The vapors that are released as a result of the oxidation of the sample pass into the flask with distilled water together with the air. There is an electrode in the flask that measures the electrical conductivity. The end of the induction period comes at the time when the electrical conductivity begins to increase rapidly. This is due to the fact that oxidation products begin to flow intensively into water and dissociate. This method allows determining the role of radical-chain reactions in the course of oxidative processes in the sample.

Method EN ISO 12205. The method involves oxidation of the sample at the temperature of $95^{\circ} \mathrm{C}$ for 16 hours. At the same time, oxygen is passed through the sample. The sample is cooled and filtered after oxidation to determine the amount of insoluble products. Resinous products are washed from the vessel and their quantity is also determined. The intensity of all processes is characterized with the total number of solid products and resinous products.

The third method is testing the samples is under native oxidation. For this, the biodiesel samples are kept in a glass dish in the dark for a year. The acid and peroxide numbers of the samples were determined every three months.

The results of the native oxidation of biodiesel samples are presented in tables 4 and 5 . It should be noted that biodiesel is quite stable when stored under normal conditions. The increase in acid and peroxide numbers 1.2-2.0 times can be considered insignificant. The standards of the most countries regulate the acid value of biodiesel at the level of $0.5-0.8 \mathrm{mg} \mathrm{KOH} / \mathrm{g} \mathrm{[5]}$.

Table 4

Dynamics of the biodiesel acid number increase during one year of storage

\begin{tabular}{|c|c|c|c|c|c|c|}
\hline \multirow{2}{*}{$\begin{array}{c}\text { Period of } \\
\text { storage, } \\
\text { months }\end{array}$} & \multicolumn{7}{|c|}{ Fatty acid methyl esters (FAME) } \\
\cline { 2 - 7 } & $\begin{array}{c}\text { Fish } \\
\text { fat }\end{array}$ & $\begin{array}{c}\text { Chicken } \\
\text { fat }\end{array}$ & $\begin{array}{c}\text { Tallow } \\
\text { (pig \& beef) }\end{array}$ & $\begin{array}{c}\text { Sunflower } \\
\text { oil }\end{array}$ & Soy oil & Palm oil \\
\hline 0 & 0,30 & 0,25 & 0,22 & 0,23 & 0,15 & 0,31 \\
\hline 3 & 0,31 & 0,29 & 0,27 & 0,26 & 0,31 & 0,37 \\
\hline 6 & 0,34 & 0,32 & 0,30 & 0,31 & 0,26 & 0,40 \\
\hline 9 & 0,36 & 0,35 & 0,31 & 0,33 & 0,28 & 0,42 \\
\hline 12 & 0,37 & 0,38 & 0,32 & 0,34 & 0,31 & 0,45 \\
\hline
\end{tabular}

Dynamics of biodiesel peroxide number increase during one year of storage

\begin{tabular}{|c|c|c|c|c|c|c|}
\hline \multirow{2}{*}{$\begin{array}{c}\text { Period of } \\
\text { storage } \\
\text { months }\end{array}$} & \multicolumn{7}{|c|}{ Fatty acid methyl esters (FAME) } \\
\cline { 2 - 7 } & $\begin{array}{c}\text { Fish } \\
\text { fat }\end{array}$ & $\begin{array}{c}\text { Chicken } \\
\text { fat }\end{array}$ & $\begin{array}{c}\text { Tallow } \\
\text { (pig \& beef) }\end{array}$ & $\begin{array}{c}\text { Sunflower } \\
\text { oil }\end{array}$ & Soy oil & Palm oil \\
\hline 0 & 15 & 17 & 10 & 22 & 6 & 18 \\
\hline 3 & 16 & 23 & 13 & 23 & 7 & 31 \\
\hline 6 & 17 & 32 & 17 & 24 & 8 & 25 \\
\hline 9 & 19 & 39 & 21 & 27 & 9 & 28 \\
\hline 12 & 19 & 40 & 21 & 27 & 10 & 30 \\
\hline
\end{tabular}

However, biodiesel is actively oxidized with increasing temperature and in the presence of oxygen. The intensity of oxidation depends on the total amount of unsaturated compounds in biodiesel when tested according to EN-14112 (determination of the induction period) (Table 6). The number of isolated double bonds in the molecule did not matter. 
The dependence of biodiesel oxidation resistance on its fatty acid composition

\begin{tabular}{|l|c|c|c|}
\hline $\begin{array}{l}\text { Fatty acid methyl } \\
\text { esters (FAME) }\end{array}$ & $\begin{array}{c}\text { The total content of } \\
\text { unsaturated } \\
\text { hydrocarbons, } \%\end{array}$ & $\begin{array}{c}\text { The content of } \\
\text { hydrocarbons with two } \\
\text { bonds and more, } \%\end{array}$ & $\begin{array}{c}\text { Oxidation resistance } \\
\text { at } 110^{\circ} \mathrm{C}, \mathrm{h}\end{array}$ \\
\hline Fish fat & 38,8 & 4,7 & 12 \\
\hline Tallow (pig \& beef) & 47,3 & 7,3 & 11 \\
\hline Palm oil & 57,3 & 56,9 & 9 \\
\hline Chicken fat & 76,4 & 33,8 & 6 \\
\hline Soy oil & 79,2 & 57,6 & 7 \\
\hline Sunflower oil & 89,5 & 20,1 & \\
\hline
\end{tabular}

Such dependence is not observed in the oxidation of biodiesel according to EN ISO 12205. This indicates that compounds prone to reaction seals without oxygen or with a very small amount of oxygen are present in the biodiesel. To know what processes occur during the oxidation of biodiesel and how to inhibit them, it is necessary to know the exact composition of biodiesel. Biodiesel may contain substances that slow down or accelerate oxidative processes. The schematic diagram of the compaction processes occurring in oil fuels is already known. Acidic oxidation products play an important role in these processes. They catalyze polymerization, polycondensation and polyesterification reactions. Their activity can be reduced by the addition of neutralizing compounds, in particular, amines. The effectiveness of some amines has been tested by us. It turned out that amines perform an inhibitory effect on the formation of sludge and tar. Alpha naphthylamine was the best of them. Some results are presented in Table 6. At the same time, the test was not conducted with «clean» biodiesel, but diesel fuel containing $7 \%$ biodiesel.

Table 7

The results of the oxidation of a mixture of diesel fuel with $7 \%$ biodiesel

\begin{tabular}{|c|c|c|c|}
\hline \multirow{3}{*}{ Fuel Sample } & \multicolumn{3}{|c|}{ Oxidative stability, $\mathrm{g} / \mathrm{m}^{3}$} \\
\hline & \multirow{2}{*}{$\begin{array}{l}\text { Non-inhibited } \\
\text { oxidation }\end{array}$} & \multicolumn{2}{|c|}{ Inhibited oxidation, additive, $0.06 \%$} \\
\hline & & Shielded phenol & Additive based on aromatic amine \\
\hline diesel without biodiesel & 4 & - & - \\
\hline \multicolumn{4}{|l|}{ diesel with biodiesel from: } \\
\hline Chicken fat & 35 & 6,5 & 4 \\
\hline Fish fat & 45 & 7 & 5 \\
\hline Sunflower oil & 55 & 8,3 & 6 \\
\hline Soy oil & 30 & 5,8 & 4 \\
\hline Palm oil & 14 & 3,5 & 4 \\
\hline Tallow (pig \& beef) & 4 & - & - \\
\hline
\end{tabular}

Low-temperature properties. Depressor additives can reduce important parameters such as the pour point and the cold filter plugging point (CFPP), but practically do not affect the cloud point.

The use of depressant additives is an efficient way to improve the low-temperature properties of diesel and increase fuel resources.

We have also studied depressor additives based on copolymers of ethylene with vinyl acetate - CEVA-1, CEVA-2, CEVA-3. They differ in their usage for fuels with different fractional composition. 
Data for FAME from sunflower oil are given as an example. These additives were tested in diesel, too. The results are presented in tables 8 and 9 .

Table 8

Low-temperature indicators of diesel with additives

\begin{tabular}{|c|c|c|c|}
\hline Property & Cloud point, ${ }^{\circ} \mathrm{C}$ & Pour point, ${ }^{\circ} \mathrm{C}$ & CFPP, ${ }^{\circ} \mathrm{C}$ \\
\hline Diesel & 3 & -13 & -4 \\
\hline$+0,05 \%$ CEVA - 1 & -2 & -24 & -12 \\
\hline$+0,05 \%$ CEVA -2 & -3 & -29 & -17 \\
\hline$+0,05 \%$ CEVA -3 & -4 & -20 & -9 \\
\hline
\end{tabular}

Table 9

Low temperature indicators of sunflower oil intermediate with additives

\begin{tabular}{|c|c|c|c|}
\hline Property & Cloud point, ${ }^{\circ} \mathrm{C}$ & Pour point, ${ }^{\circ} \mathrm{C}$ & CFPP, ${ }^{\circ} \mathrm{C}$ \\
\hline FAME of Sunflower oil & 1 & -14 & -6 \\
\hline$+0,05 \%$ CEVA -1 & 1 & -16 & -7 \\
\hline$+0,05 \%$ CEVA -2 & -2 & -18 & -8 \\
\hline$+0,05 \%$ CEVA -3 & 1 & -15 & -6 \\
\hline
\end{tabular}

The fractional composition of the methyl esters of fatty acids of sunflower oil has been taken into account for a more detailed study (Table 1). The influence of depressant additives on narrow fractions of diesel has been studied extensively. The results of the studies are presented in Table 10.

Table 10

Low temperature parameters of diesel fractions with additives

\begin{tabular}{|c|c|c|c|}
\hline Property & Cloud point, ${ }^{\circ} \mathrm{C}$ & Pour point, ${ }^{\circ} \mathrm{C}$ & CFPP, ${ }^{\circ} \mathrm{C}$ \\
\hline Fraction $180-220^{\circ} \mathrm{C}$ & -22 & -33 & -28 \\
\hline$+0,05 \%$ CEVA -1 & -20 & -38 & -36 \\
\hline$+0,05 \%$ CEVA -2 & -20 & -39 & -37 \\
\hline$+0,05 \%$ CEVA -3 & -20 & -34 & -29 \\
\hline Fraction $220-260^{\circ} \mathrm{C}$ & -28 & -31 & -26 \\
\hline$+0,05 \%$ CEVA -1 & -30 & -33 & -37 \\
\hline$+0,05 \%$ CEVA -2 & -30 & -39 & -28 \\
\hline$+0,05 \%$ CEVA -3 & -24 & -32 & -17 \\
\hline Fraction $260-300{ }^{\circ} \mathrm{C}$ & -12 & -22 & -20 \\
\hline$+0,05 \% \mathrm{CEVA}-1$ & -15 & -36 & -22 \\
\hline$+0,05 \% \mathrm{CEVA}-2$ & -16 & -37 & -17 \\
\hline$+0,05 \% \mathrm{CEVA}-3$ & -12 & -23 & 2 \\
\hline Fraction $300-360^{\circ} \mathrm{C}$ & 4 & -12 & -3 \\
\hline$+0,05 \% \mathrm{CEVA}-1$ & 1 & -19 & -4 \\
\hline$+0,05 \% \mathrm{CEVA}-2$ & 1 & -20 & 2 \\
\hline$+0,05 \% \mathrm{CEVA}-3$ & 4 & -12 & \\
\hline
\end{tabular}

The research results have shown that depressor additives work the worst in the diesel fraction of $300-360^{\circ} \mathrm{C}$. FAME of sunflower oil has exactly this fractional range.

The depression of pour point and CFPP with depressor additives are shown in diagrams (Fig. 4-5). Depressor additive CEVA-2 operates most effectively. 


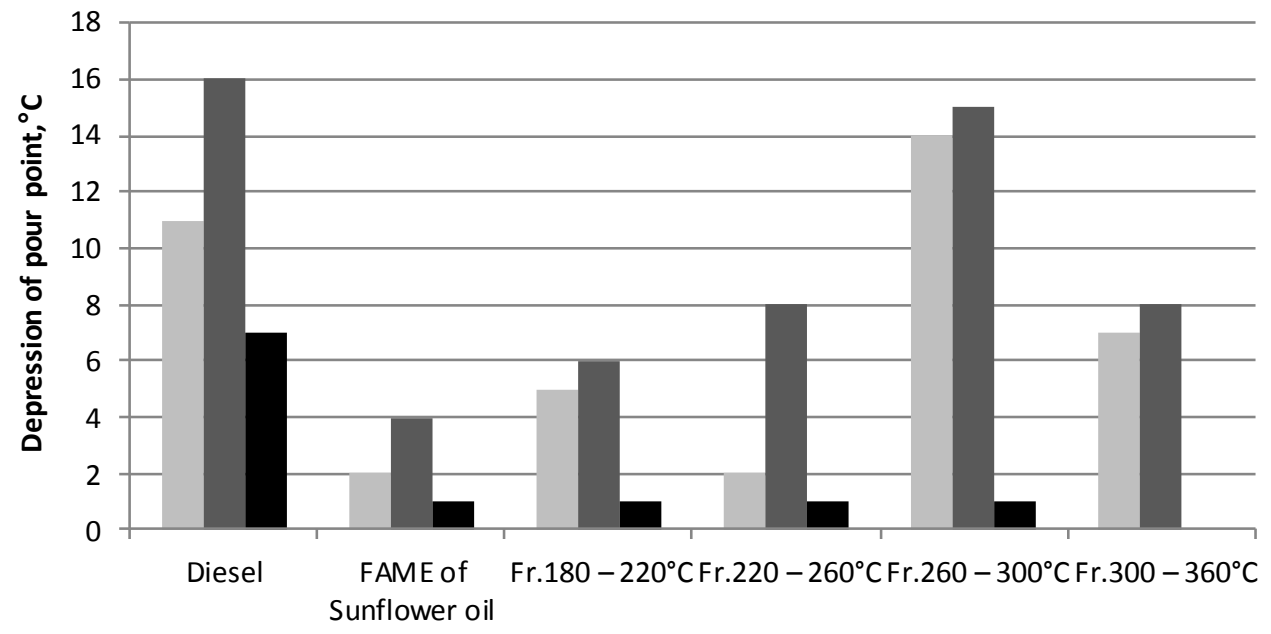

CEVA-1 —CEVA-2 —CEVA-3

Fig. 4. Depression of pour point

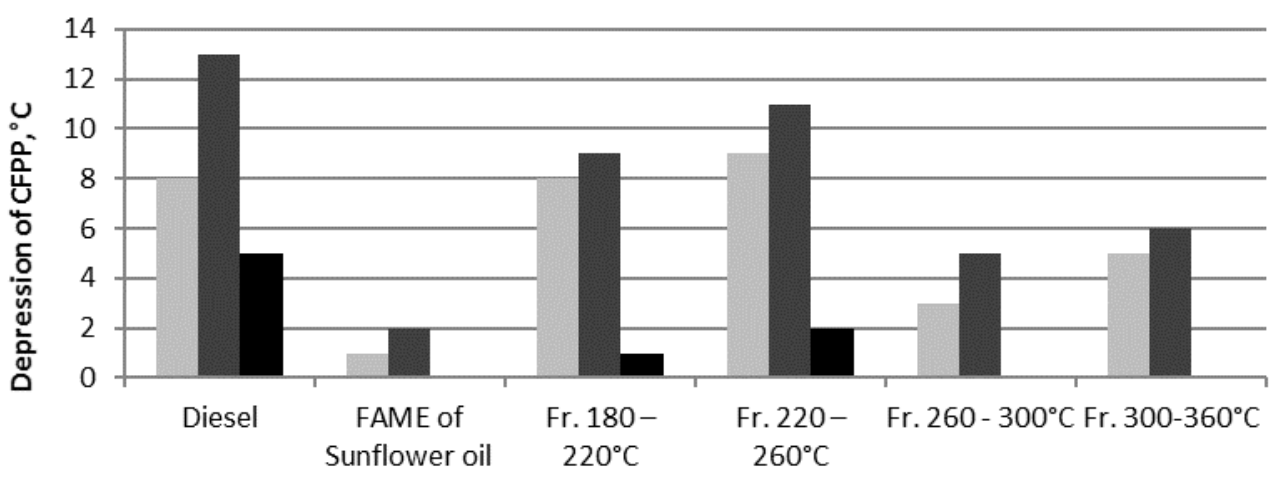

aCEVA-1 $\square$ CEVA-2 @CEVA-3

Fig. 5. Depression of CFPP

The content of methyl esters of fatty acids which is expedient to use in a mixture of diesel fuels does not exceed $30 \%$ by weight. Such mixtures can be used in diesel engines without constructive changes.

Table 11

Low temperature properties of the diesel fuel mixture and FAME of sunflower oil

\begin{tabular}{|c|c|c|c|}
\hline Property & Cloud point, ${ }^{\circ} \mathrm{C}$ & Pour point, ${ }^{\circ} \mathrm{C}$ & $\mathrm{CFPP},{ }^{\circ} \mathrm{C}$ \\
\hline $70 \%$ Diesel +30 \% FAME of Sunflower oil & 3 & -8 & -4 \\
\hline$+0,05 \%$ CEVA - & -1 & -17 & -13 \\
\hline$+0,05 \%$ CEVA - 2 & -1 & -20 & -16 \\
\hline$+0,05 \%$ CEVA -3 & -1 & -13 & -9 \\
\hline
\end{tabular}


Additive CEVA-2 reduces the pour point by $12{ }^{\circ} \mathrm{C}$, and CFPP - by $9{ }^{\circ} \mathrm{C}$. Low temperature properties of diesel fractions mixtures with FAME and depressor additive of CEVA-2 has been determined. The results are presented in Table 12.

Table 12

Low temperature properties of diesel fractions mixtures andFAME of sunflower oil

\begin{tabular}{|c|c|c|c|}
\hline Property & Cloud point,${ }^{\circ} \mathrm{C}$ & Pour point, ${ }^{\circ} \mathrm{C}$ & $\mathrm{CFPP},{ }^{\circ} \mathrm{C}$ \\
\hline $70 \%$ fr. $180-220{ }^{\circ} \mathrm{C}+30 \%$ FAME of Sunflower oil & -15 & -21 & -17 \\
\hline$+0,05 \%$ CEVA -2 & -19 & -28 & -23 \\
\hline $70 \%$ fr. $220-260{ }^{\circ} \mathrm{C}+30 \%$ FAME of Sunflower oil & -12 & -20 & -18 \\
\hline$+0,05 \%$ CEVA -2 & -15 & -25 & -22 \\
\hline $70 \%$ fr. $260-300{ }^{\circ} \mathrm{C}+30 \%$ FAME of Sunflower oil & -8 & -12 & -11 \\
\hline$+0,05 \%$ CEVA -2 & -10 & -18 & -15 \\
\hline $70 \%$ fr. $300-360{ }^{\circ} \mathrm{C}+30 \%$ FAME of Sunflower oil & 8 & 2 & 4 \\
\hline$+0,05 \%$ CEVA -2 & 6 & -4 & -1 \\
\hline
\end{tabular}

Additive BEC-2 effectively operates in the mixtures of all fractions with FAME. Pour points are reduced by $5 \div 7{ }^{\circ} \mathrm{C}$, and the CFPP are reduced by $4 \div 6{ }^{\circ} \mathrm{C}$. In the fraction of $300-360{ }^{\circ} \mathrm{C}$, the pour point is reduced by $6{ }^{\circ} \mathrm{C}$, and CFPP - by $5^{\circ} \mathrm{C}$.

The low-temperature component (LTC) has been added to improve the low-temperature properties of the mixed fuel, together with other additives. The results obtained are shown in Table 13.

Table 13

Low temperature properties of the diesel mixture with FAME of sunflower oil and with the addition of lowtemperature component (LTC)

\begin{tabular}{|c|c|c|c|}
\hline Property & Cloud point,${ }^{\circ} \mathrm{C}$ & Pour point, ${ }^{\circ} \mathrm{C}$ & $\mathrm{CFPP},{ }^{\circ} \mathrm{C}$ \\
\hline $70 \%$ Diesel $+30 \%(70 \%$ FAME $+30 \%$ LTC $)$ & -6 & -16 & -15 \\
\hline$+0,05 \%$ CEVA - & -9 & -29 & -23 \\
\hline$+0,05 \%$ CEVA - & -10 & -32 & -25 \\
\hline$+0,05 \%$ CEVA -3 & -7 & -16 & -16 \\
\hline
\end{tabular}

Introduction of the low-temperature component in the composition of diesel reduces the pour point by $8{ }^{\circ} \mathrm{C}$, and CFPP - by $11^{\circ} \mathrm{C}$. When adding the CEVA-2 additive at the concentration of $0.05 \%$, the depression of the pour point and CFPP is by $24{ }^{\circ} \mathrm{C}$ and $21{ }^{\circ} \mathrm{C}$, respectively. CFPP of fuel composition meets the requirements of the standard for winter diesel.

The combined effect of the low-temperature component and the depressant additive on the low-temperature properties of diesel fuel fractions with FAME has been studied. Data is given in Table 14.

Table 14

Low temperature indicators of the mixture of diesel fractions, FAME of sunflower oil with the low temperature component added

\begin{tabular}{|c|c|c|c|}
\hline Property & Cloud point, ${ }^{\circ} \mathrm{C}$ & Pour point, ${ }^{\circ} \mathrm{C}$ & $\mathrm{CFPP},{ }^{\circ} \mathrm{C}$ \\
\hline $70 \%$ fr. $180-220^{\circ} \mathrm{C}+30 \%(70 \%$ FAME $+30 \%$ LTC $)$ & -23 & -28 & -25 \\
\hline$+0,05 \%$ CEVA -2 & -25 & -39 & -28 \\
\hline $70 \%$ fr. $220-260{ }^{\circ} \mathrm{C}+30 \%(70 \%$ FAME $+30 \%$ LTC $)$ & -18 & -27 & -23 \\
\hline$+0,05 \%$ CEVA -2 & -19 & -37 & -26 \\
\hline $70 \%$ fr. $260-300{ }^{\circ} \mathrm{C}+30 \%(70 \%$ FAME $+30 \%$ LTC $)$ & -10 & -18 & -14 \\
\hline$+0.05 \%$ CEVA -2 & -12 & -25 & -17 \\
\hline $70 \%$ fr. $300-360{ }^{\circ} \mathrm{C}+30 \%(70 \%$ FAME $+30 \%$ LTC $)$ & 5 & -2 & 4 \\
\hline$+0,05 \%$ CEVA -2 & 3 & -10 & -3 \\
\hline
\end{tabular}


The obtained results are presented in the form of diagrams, which illustrate depression of the pour point and the CFPP of mixed fuels with depressor additives and LTC.

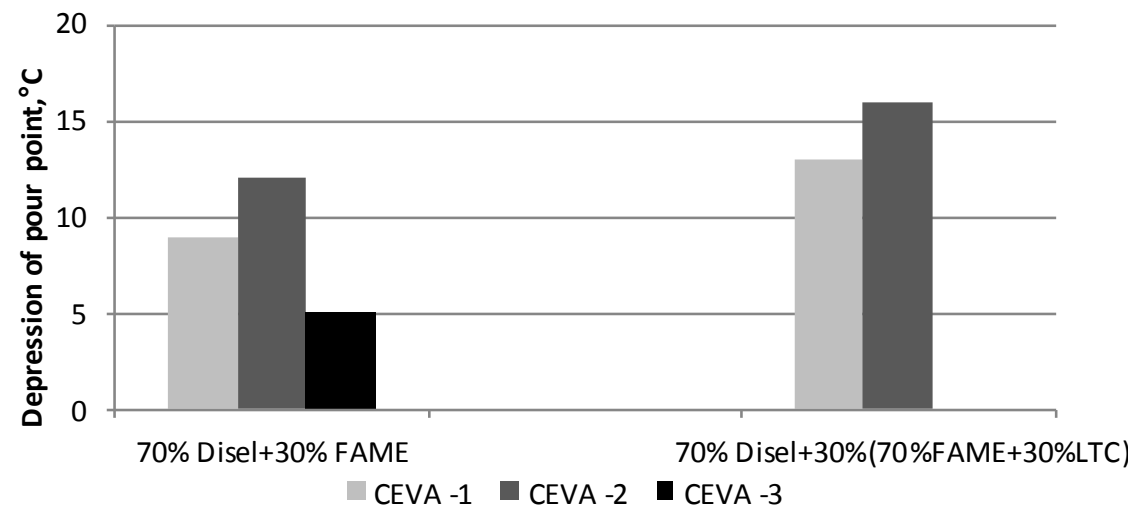

Fig. 6. Depression of pour point

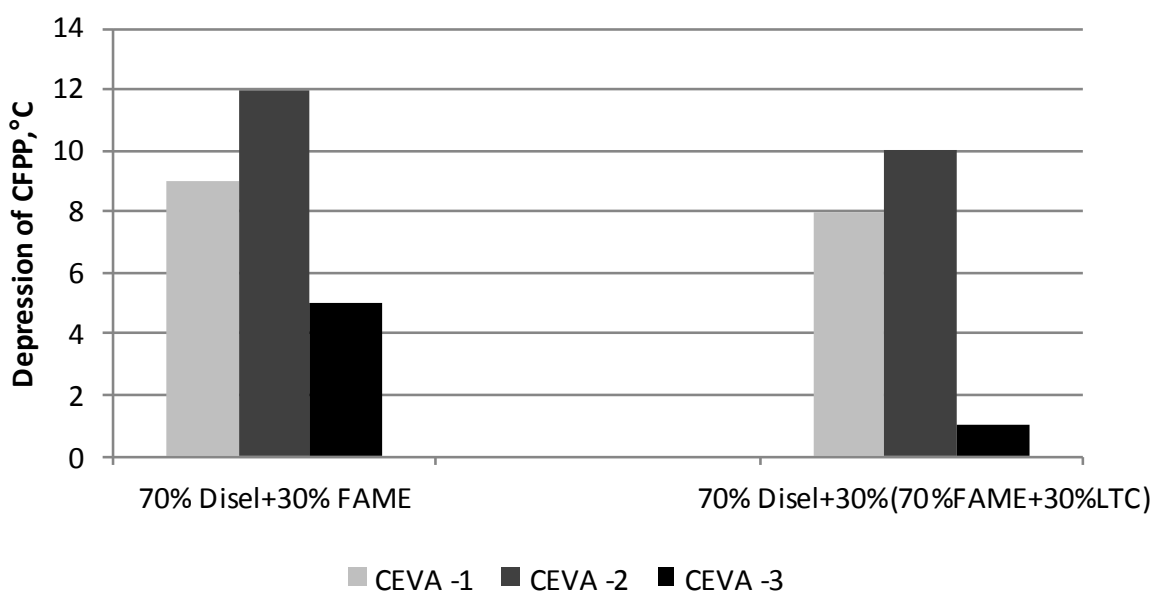

Fig. 7. Depression of CFPP

Based on the sample of FAME sunflower oil, it has been shown that up to $30 \%$ FAME can be used in a diesel fuel composition at low temperatures at the presence of the low temperature component and the depressant additive based on ethylene vinyl acetate copolymers.

Combustion rate of diesel fuel. Data about cetane numbers $(\mathrm{CN})$ of the FAME from various sources vary considerably, but the general opinion is that the values of the $\mathrm{CN}$ of fatty acid esters are higher than those of diesel fractions. The cetane numbers of the FAME samples have been determined (Table 1), and the values are in the range of 52-56 units.

Lubricity. It is well known that long-chain carboxylic acids and their derivatives have excellent lubricating properties. The effect of chicken fat based FAME additive on the average diameter of a diesel wear spot $\left(d_{\text {mean value }}\right)$ is presented as an example at Fig.6. Tests have been conducted on a standard standHFRR [5]. The anti-wear properties of the fuel are brought to the normal (less than 460 microns) by adding 1-2\% FAME.

With further increase in concentration, $d_{\text {mean value }}$ value has become stabile at 200 microns. 


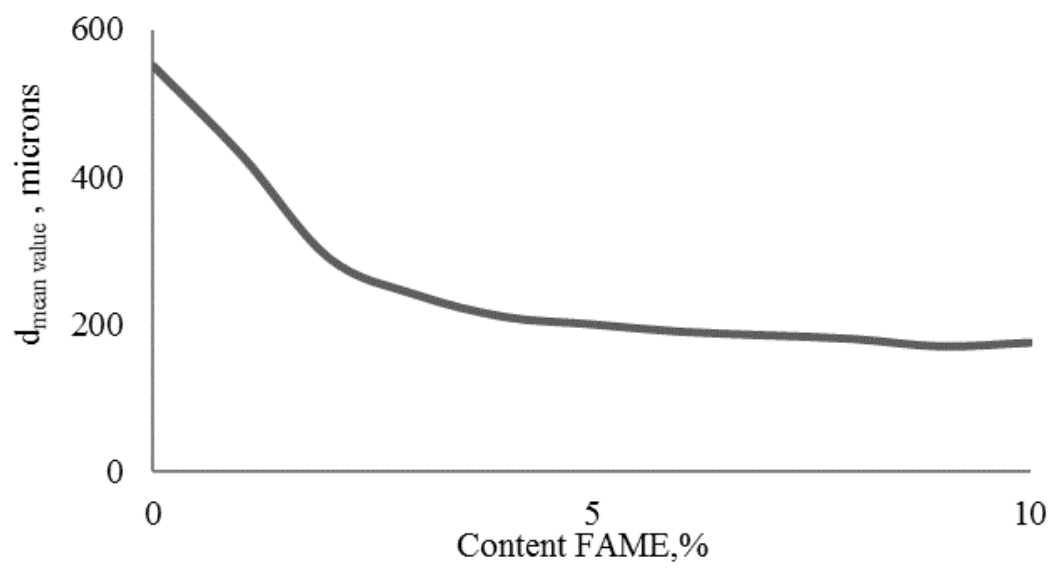

Fig. 8. Effect of chicken fat based FAME additive on the average wear spot diameter of diesel

Energy properties. Biodiesel, depending on the origin, contains from 10 to $14 \% \mathrm{~m} / \mathrm{m}$ oxygen. Accordingly, its calorific value is reduced by this value (Table 15). This will reduce the power reserve of the car. But the calorific value does not presumably affect the power characteristics of the engine, since the filling ratio of the cylinder will change due to the smaller air supply. However, there is a need to adjust the high pressure fuel pump.

Table 15

Calorific Valueof FAME

\begin{tabular}{|c|c|c|c|c|c|c|c|c|}
\hline \multirow[b]{2}{*}{ Property } & \multirow[b]{2}{*}{ Diesel } & \multicolumn{7}{|c|}{ Fatty acid methyl esters (FAME) } \\
\hline & & $\begin{array}{c}\text { Rape } \\
\text { oil }\end{array}$ & $\begin{array}{l}\text { Chicken } \\
\text { fat }\end{array}$ & Fish fat & Palm oil & $\begin{array}{l}\text { Soy } \\
\text { oil }\end{array}$ & $\begin{array}{c}\text { Sunflower } \\
\text { oil }\end{array}$ & $\begin{array}{l}\text { Tallow } \\
\text { (pig \& } \\
\text { beef) }\end{array}$ \\
\hline $\begin{array}{l}\text { Sulfur content, } \\
\% \mathrm{~m} / \mathrm{m}\end{array}$ & $1 * 10^{-4}$ & 0 & $9 * 10^{-4}$ & $2 * 10^{-4}$ & 0 & 0 & 0 & 0 \\
\hline $\begin{array}{l}\text { Lower heating } \\
\text { value, } \mathrm{kJ} / \mathrm{kg}\end{array}$ & 42617 & 38088 & 38160 & 37017 & 38236 & 38206 & 38120 & 38098 \\
\hline
\end{tabular}

Mixed diesel fuels containing methyl esters of fatty acids have the closest quality indicators to diesel fuel. Studies of the physical-chemical properties of the FAMEs suggest that its concentration in the mixed fuel can be increased up to $30 \%$. The obtained mixture is subject to the use of appropriate additives. The introduction of the maximum number of the FAME from different raw materials into diesel fuel is acceptable. The FAME has a positive effect on the environmental performance of the mixture, lubricity. This gives advantages and in addition increases the resource of diesel fuel in Ukraine.

\section{PEФЕРАТ \\ Олена Шевченко, Валерія Каменєва, Альона Шкекіна \\ Украӥнський державний хіміко-технологічний університет elshevchenko7@gmail.com,kameneva1000@gmail.com,alyona.shkekina@gmail.com \\ МОДИФІКАЦІЯ СКЛАДУ ДИЗЕЛЬНОГО ПАЛИВА МЕТИЛОВИМИ ЕФІРАМИ ЖИРНИХ КИСЛОТ 3 НЕЇСТІВНИХ ЖИРІВ}

Розглянуто сучасний стан технології отримання метилових ефірів жирних кислот (МЕЖК) 3 нехарчових жирів та олив, дано оцінку сировинної бази на Україні, обгрунтовано можливість переробки. Описано переваги і недоліки жировміщуючої сировини. Досліджено фізико-хімічні та екплуатаційні властивості МЕЖК з нехарчових жирів і олій. Обговорено властивості, що лімітують 
кількість альтернативного компонента в дизельному паливі на підставі його жирнокислотного складу, окисної стабільності, в'язкісно-температурних характеристик, низькотемпературних властивостей. Підібрано присадки, що покращують низькотемпературні і антиокислювальні властивості сумішей біодизеля з нафтовим паливом. Висловлено припущення про можливе збільшення концентрації МЕЖК в сумішевих паливах до $30 \%$.

Ключові слова: метилові естери жирних кислот, нехарчові жири.

\title{
PЕФЕРАТ
}

Елена Шевченко, Валерия Каменева, Алёна Шкекина

Украинский государственный химико-технологический университет

elshevchenko7@gmail.com,kameneva1000@gmail.com,alyona.shkekina@gmail.com

\section{МОДИФИКАЦИЯ СОСТАВА ДИЗЕЛЬНОГО ТОПЛИВА МЕТИЛОВЫМИ ЭФИРАМИ} ЖИРНЫХ КИСЛОТ ИЗ НЕПИЩЕВЫХ ЖИРОВ

Рассмотрено современное состояние технологии получения метиловых эфиров жирных кислот (МЭЖК) из непищевых жиров и масел, дана оценка сырьевой базы на Украине, обоснована возможность переработки. Описаны преимущества и недостатки жиросодержащего сырья. Исследованы физико-химические и экплуатационные свойства МЭЖК из непищевых жиров и масел. Обсуждены свойства лимитирующие количество альтернативногокомпонента в дизельном топливе на основании его жирнокислотного состава, окислительной стабильности, вязкостно - температурных характеристик, низкотемпературных свойств. Подобраны присадки, улучшающие низкотемпературные и антиокислительные свойства смесей биодизеля с нефтяным топливом. Высказано предположение о возможном увеличении концентрации МЭЖК в смесевых топливах до $30 \%$.

Ключевые слова: метиловые ефиры жирных кислот, непищевые жиры.

\author{
ABSTRACT \\ Elena Shevchenko, Valeriia Kameneva, Alyona Shkekina \\ Ukrainian State University of Chemical Engineering \\ elshevchenko7@gmail.com,kameneva1000@gmail.com,alyona.shkekina@gmail.com \\ MODIFICATION OF DIESEL FUEL COMPOSITION WITH METHYL ESTERS \\ OF FATTY ACIDS FROM NON-EDIBLE FATS
}

The state of the art of producing fatty acid methyl esters (FAME) from non-edible fats and oils has been reviewed. Evaluation of the resource base in Ukraine is given. The possibility of processing is substantiated. The advantages and disadvantages of fat-containing raw materials are described. The physicochemical and operational properties of FAME from non-edible fats and oils have been investigated. The properties that limit the amount of the alternative component in diesel fuel have been discussed on the basis of the fatty acid composition of the alternative component, its oxidation stability, viscosity-temperature characteristics and low-temperature properties. Additives that improve the low-temperature and antioxidant properties of mixtures of FAME with oil supplements are selected. The possible increase in the concentration of FAME in mixed fuels up to $30 \%$ has been assumed.

Key words: fatty acid methyl esters, non food fats.

\section{REFERENCES}

1. World biofuels industry: general characteristics, history and factors of the industry development [Electronic reference]. - 2012. - Access mode: http://www.beintrend.ru/2012-10-03-15-15-51.

2. Oblashchikova I. R. Research on rapeseed oil as the basis for alternative lubricants: Abstract. Diss. Cand. Tech. Sciences: 17.09.04 / Oblashchikova Irina Rudolfovna; Russian State University of Oil and Gas. THEM. Gubkin. - M., 2004. -32 p.

3. Zolotareva O. Where the biofuel industry directs / O. Zolotaryova, E. Shniukova // Bulletin of the National Academy of Sciences of Ukraine. - 2010. - No. 4. - P. 10-20.

4. Kapustin V. M. Biodiesel fuel: advantages, disadvantages and perspectives of industrial production / V. M. Kapustin, S. A. Karpov, A. I. Saidahmedov // Oil refining and petrochemistry. Scientific and technological achievements and best practices. - 2011. - № 4. - P. 49-54.

5. Rand S. Dzh. Analysis of petroleum products. Methods, their purpose and application: Transl. from English 8th ed. / S.J. Rand, et al; by ed. E. A. Novikova, L. G. Nekhamkina. - St. Petersburg: CSC "Profession", 2014. - 664 p. 